Boise State University

ScholarWorks

$11-15-2014$

\title{
Warm Water Benthic Foraminifera Document the Pennsylvanian- permian Warming and Cooling Events - The Record from the Western Pangea Tropical Shelves
}

Vladimir Davydov

Boise State University

\section{Publication Information}

Davydov, Vladimir. (2014). "Warm Water Benthic Foraminifera Document the Pennsylvanian-permian Warming and Cooling Events - The Record from the Western Pangea Tropical Shelves". Palaeogeography, Palaeoclimatology, Palaeoecology, 414, 284-295. https://doi.org/10.1016/j.palaeo.2014.09.013

NOTICE: this is the author's version of a work that was accepted for publication in Palaeogeography, Palaeoclimatology, Palaeoecology. Changes resulting from the publishing process, such as peer review, editing, corrections, structural formatting, and other quality control mechanisms may not be reflected in this document. Changes may have been made to this work since it was submitted for publication. A definitive version was subsequently published in Palaeogeography, Palaeoclimatology, Palaeoecology, (In Press). doi: 10.1016/ j.palaeo.2014.09.013 


\section{Vladimir Davydov}

Warm water benthic foraminifera document the Pennsylvanian-Permian warming and cooling events - the record from the Western Pangea tropical shelves

Permian Research Institute, Boise State University and Kazan (Volga Region) Federal University , Russia; 1910 University Drive, Department of Geosciences, Boise State University, Boise, Idaho, USA; vdavydov@boisestate.edu; fax: (208) 4264061.

\section{ABSTRACT.}

Shallow warm water benthic foraminifera (SWWBF), including all larger fusulinids (symbiont-bearing benthic foraminifera), are among the best indicators of paleoclimate and paleogeography in the Carboniferous and Permian. The distribution of benthic foraminifera in space and time constrain important tectonic, paleogeographic and climatic events at a global scale. The North American shelves during Pennsylvanian and Permian time - though geographically within the tropical belt - are characterized by temperate environments with significantly lower foraminifera diversification and rare occurrences of warm water Tethyan forms, that are in general appear in the region as a migration entities. Such environments allow documentation of warming episodes associated with sudden immigration of warm water and exotic forms of SWWBF that evolved elsewhere into the area. First occurrence datum (FOD) of the forms exotic to North America during warming episodes are always delayed in respect of their First Appearance Datum (FAD) elsewhere. The time of delay and taxonomic diversity of fusulinids in North America shelves depended on the scale and intensity of the warming episodes. Cooling events, on the other hand, are associated with decreased taxonomic diversity 
and appearances of endemic forms characteristic only of temperate water provinces. The

occurrence of these forms in Boreal and North American provinces appears to be isochronous, as their environments are uniform and induce their uniform and isochronous distribution. Several warming and cooling episodes during Pennsyllvanian-Permian time are recognized. The differences between taxonomic variations in each event could potentially be used for provisional estimation of the degree of climatic change. A strong link between biotic and climatic events in North American province and the similarity of biotic changes in the North American and other provinces suggests that paleoclimatic events in North American province were controlled by global factors.

KEY-WORDS. North America, Late Paleozoic, paleoclimate fluctuations, benthic foraminifera, warming and cooling events.

\section{Introduction}

The Late Paleozoic is commonly regarded as a time of alterations global greenhouseicehouse climate. The most recent data suggest multiple phases of glaciation, although the number of phases and their age constraints are still debated (Isbell et al., 2003; Montanez et al., 2007; Fielding et al., 2008b; Isbell et al., 2012; Montanez and Poulsen, 2013). The constraints and nature of the interglacial phases are still poorly understood.

Marine biotas are sensitive to local, regional and global environmental changes and exceptionally well—studied shallow water benthic foraminifera are among the best indicators for paleoenvironments (Murray, 2006 and references herewith). The Cenozoic record of larger benthic foraminifera diversity (Hallock et al., 1991) shows a strong correlation with well—— studied climatic changes for that time (Zachos et al., 2001). Furthermore, several other recent 
studies suggest strong correlations of diversity of marine microorganisms, including those with symbionts, and sea surface temperature (Semeniuk, 2001; Fuhrman et al., 2008; Mayhew et al., 2012).

Several paradoxes exist in regards to the distributions of late Paleozoic faunas on North American shelves. During this time, Western Pangea shelves around Texas, and New Mexico and South Nevada were at tropical paleolatitude (Blakey, 2008) (Fig. 1). The taxonomic diversity of modern shallow - water organisms is assumed to be the highest at the tropicsubtropic environments (Huston, 1994; Buzas et al., 2002. ; Jablonski et al., 2006). However, the diversity of shallow benthic foraminifera in North American shelves is two to three times lower than that of the eastern shelves of Pangea (Urals, Donets Basins, Central Asia etc.) (Groves and Wang, 2009; Davydov et al., 2012). Even at higher Pennsylvanian paleolatitude in the present — day Arctic region (Timan-Pechora, Spitsbergen and North Greenland) the diversity of foraminifera was at least twice as high as on North American tropical shelves (Fig. 2). Some workers might suggest that the apparent higher diversity of the eastern Pangea shelves is because Russian workers have been more prone to "splitting", thus creating more taxa. However, taxa at generic level are generally accepted by excathedral international workers, including specialists from North America (Nassichuk and Wilde, 1977; Rui Lin et al., 1994; Ross, 1995). Some genera are recognized in North America when the concepts of the Russian taxonomy become available for the students in greater details (Wahlman et al., 1997).

The second paradox refers to the fact that the FOD of the majority of North American foraminifera genera in the western Pangea shelves possess the lag of 2-3 Ma and sometimes up to $5 \mathrm{Ma}$ in comparison to the FAD of these genera elsewhere. At the same time, none of the genera occur in North American shelves earlier than elsewhere (Ross, 1995). 
Finally, the third phenomena and paradox is the common occurrence of faunas characteristic of temperate climate including foraminifera, brachiopods, pelecypods and other fossils like Palaeoaplysina (Mamet, 1977; Ross, 1995; Clapham, 2010; Wahlman and Konovalova, 2002; Weldon and Shi, 2003 Perez-Huerta, 2007; Hanken and Nielsen, 2013, ) in North American at tropical paleolatitude.

A recently proposed model of the interaction between climate and tropical benthic foraminifera (Davydov and Arefifard, 2013; Davydov et al., 2013) and assessments of the Late Paleozoic climatic fluctuations are applied here in order to understand and evaluate paradoxes and problems mentioned above. The data on the global shallow water benthic foraminifera diversity variations are combined here with the pattern of their immigration from tropics into the North American shelves and the link between biotic and climate events is proposed and documented. Although Mississippian shallow water benthic foraminifera do not possessed symbionts, their evolution and distribution pattern are consistent with the larger symbiontbearing shallow water benthic foraminifera such as fusulinids.

\section{Paleobiology and Paleoecology of Fusulinaceans}

Although extinct, Late Paleozoic shallow warm water benthic foraminifers (including Ammodiscida, Endothyroida and Fusulinoida, by Vdovenko et al., 1993 and RauserChernousova et al., 1996) played a leading role in benthic assemblages during the Late Paleozoic and: (a) dominated numerically in micro_-benthic communities; (b) were globally wide spread within the tropics and subtropics; (c) evolved rapidly and reached highest taxonomic diversity among micro- benthic communities. These foraminifera, including the most important group such as fusulinids were mostly distributed within carbonate to mixed carbonate - siliciclastic 
shallow - water settings (Ross, 1995) in the tropical-subtropical belt (up to $35-40^{\circ} \mathrm{S} / \mathrm{N}$

paleolatitude). Based on similarities in size and test morphology of fusulinids, as well as with the biofacies associations of modern larger benthic foraminifera (Beavington-Penney and Racey, 2004; Hohenegger, 2004; Murray, 2006), the majority of fusulinids are assumed to have hosted photosynthetic symbionts (Ross, 1982; Vachard et al., 2004). Benthic foraminifera are poikilothermic, i.e. their body temperature is very close to that of the surrounding water, and therefore, they responds very quickly to even small changes in the ambient water temperature (Beavington-Penney and Racey, 2004). Temperature is generally considered to be the most important physical factor influencing the distribution of benthic foraminifera and particularly on symbiont-bearing protistans (Murrey, 2006; Fuhrman et al., 2008; Afzal et al., 2011). Fuhrman et al. (2008) analyzed several parameters that control the taxonomic diversity of symbiont — bearing protistants, such as salinity, food supplies, chlorophyll, average primary productivity and surface water temperature.. It was clearly recognized that taxonomic richness strongly and positively correlates with water temperature at the time of sampling, and even more strongly with average annual sea — surface temperature. These data and analyses (Fuhrman et al., 2008) support the hypothesis that diversity of symbiont - bearing protistans as well as the other shallow water benthic foraminifera in a given habitat is largely generated and maintained by effects of temperature on the kinetics of metabolism. The metabolic rate, which increases exponentially with increasing temperature, sets the pace of life and hence the rates of nearly all biological activities.

Shallow — water assemblages of present— day shallow water benthic foraminifera in optimal water temperatures $\left(20-30^{\circ} \mathrm{C}\right)$ are generally much more diverse than those in temperatures greater than $30^{\circ} \mathrm{C}$ or less than $20^{\circ} \mathrm{C}$ (Fig. 3) (Beavington-Penney and Racey, 
2004; Hohenegger, 2004; Murray, 2006; Afzal et al., 2011). Similar changes in diversity are apparent in the latitudinal distribution of the late Paleozoic benthic shallow water foraminifera and these are assumed to correspond to tropical-subtropical temperature changes (Ross, 1995). During global warm episodes, benthic shallow water foraminifera migrated to higher latitudes. By contrast, cooling led to migration of most of these foraminiferal faunas from higher to lower latitudes, stepwise extinction of some of the larger taxa, increasing provincialism, and the preferential survival of eurytopic faunas adapted for a broader range of facies and environments (Stanley, 1984; Ozawa, 1987; Kalvoda, 2002; Mayhew et al., 2012; ).

Climatic fluctuations and velocity of climate change are most significant at midlatitudes, as has been shown in the modern-world (Burrows et al., 2011) and Permian models (Winguth et al., 2002). SWWBF faunas provide a particularly sensitive indicator for climate change in these areas. Permian climate simulation models (Winguth et al., 2002) suggest a significant 5-7 $\mathrm{C}^{\circ}$ latitudinal shift in average sea-surface temperature and associated climatic belts under glacial versus non — glacial (warm) climatic states. This model for the midlatitudinal regions has been successfully applied to help understand climate dynamics during late Gzhelian (latest Pennsylvanian of Timor and Australia) (Davydov et al., 2013a) and Guadalupian (Oman-Zagros areas) time (Davydov and Arefifard, 2013).

\section{Migrational pattern and dispersal of shallow warm water benthic foraminifera between Tethys and North America}

In terms of the establishment of the direction pattern and interaction of shallow warm water foraminifera between different paleobiogeographic provinces, Thompson (1967) was the 
first who noted the emigrational character of the occurrences of some important SWWBF forms in North America. For the pre-middle Permian forms he assumed east to west migration from Tethyan basins through the Arctic (North Greenland and Canadian Archipelago). Particular Uralian-Franklinian province that extends from the Urals in the east to the Nevada in the west has been proposed by Ross $(1967,1995)$. Because of uniform fauna within the province from Urals to Nevada it suggested frequent connections between these regions.

The Urals to North America migrational pattern specifically for Triticites was assumed by Davydov (1997b) and Villa and Wahlman (2007) and for Profusulinella by Groves et al., (2007). The latter genus appears in Tethys during early middle Bashkirian time and migrated to North America in the early Moscovian, as suggested by Groves et al. (2007), through the northern passage alone northern margin of Pangea which was named Franklinian corridor. Triticites appears in western Tethys in the early middle Kasimovian (Davydov, 1990) and migrated to North America in late Kasimovian (Dennis cylothem) time (Davydov, 1997b; Villa and Wahlman, 2007).

It should be noted, however, that east —west migration through the Franklinian corridor was not the only way of dispersal for the SWWBF. The east-west migration potentially was possible only during Pennsylvanian-Cisuralian time until the northern margin of Pangea reached the temperate to cold climatic belt due to movement of the continent toward the north (Beauchamp, 1994). Thus, since Kungurian time the connection through the Franklinian corridor was not possible even potentially. At the same time, the migrations of the SWWBF in North American shelves occur in Kungurian and post-Kungurian times until the late Capitanian (Thompson, 1967). This clearly suggest west to east migration of the SWWBF from eastern Tethys to North American realm. Therefore the interprovincial connections could potentially 
being permanent and migration of the new SWWBF faunas to North America could occur at any time during Pennsylvanian and Permian from both east—west and west—east directions, e.i. through the Franklinian corridor or from eastern Tethys directly to North American shelves. There are three cases where east to west connection between Arctic/Urals and North SWWBF is undoubtful. Moscovian Wedekindellina, early Kasimovian Eowaeringella and early Sakmarian Eoparafusulina were the genera that are endemic to Arctic/Urals and North America provinces. The two former genera are not known elsewhere. Eoparafusulina is widely distributed in Panthalassa and Peri—Gondwanan regions (Ueno, 2006; Davydov and Arefifard, 2007), but the earliest appearance documented in Russian Arctic (Grozdilova and Lebedeva, 1961).

\section{Temperate environments in North American shelves during Late Paleozoic}

Several studies have noted a significantly lower diversity of Late Paleozoic foraminifera in North America when compared with corresponding assemblages in Tethys and even in Boreal faunas (Fig. 1) (Mamet, 1977; Davydov, 2008; Groves and Wang, 2009;) but no reasons for this situation have been offered. A possible reason proposed here is that North American shelves in tropical paleolatitude had predominantly temperate paleoclimates (Davydov, 2008, 2013). ThePermian regional climate cooling of western Laurentia has been documented from several benthic fossils (Clapham, 2010). Similarly, several temperate—index fossils, such as cold—water Conulariids and other pelecypods were documented within the North America shelves in Idaho, Nevada, and West Texas, (Kauffman and Runnegar, 1975; Meldon and Shi, 2003).

Potential glendonites in the Bashkirian and middle Moscovian of Nevada were reported from the western margin of North American craton (Bishop et al., 2007; and personal data of the author). In addition possible evidence of alpine glaciation at this tropical paleolatitude zone has been 
presented for the Devonian (Brezinski et al., 2010) and also proposed for the Pennsylvanian in the Ancestral Rocky Mountains (Soreghan et al., 2008). Because of the shift of cool—water thermocline southwards along the Laurentia, the environment in the shelves $t$ was similar to as in the mid - latitudes elsewhere in Boreal and Peri-Gondwanan provinces (Davydov and Arefifard, 2013; Davydov et al., 2013). Further evidence of late Paleozoic temperate paleoclimatic conditions in western Pangean tropical paleolatitude is the larger foraminifera thermocline, which is two to three times shallower than in eastern Pangean tropical to subtropical paleolatitude.

The data from modern tropical shelves suggest that the average thermocline range for the temperature sensitive foraminifera is 50-70 m with the maximum depth at $140 \mathrm{~m}$ (Figs. 2-3) (Beavington-Penney and Racey, 2004; Hohenegger, 2004). The studies in the Carboniferous subtropics in Moscow Basin at about 25-30 $\mathrm{N}$ paleolatitude in the eastern Pangea shelves suggest the fusulinid's thermocline range is at about 20-30 m with maximum depth at 40 m (Baranova and Kabanov, 2003). There are two studies on fusulinid paleobathymetric distibutions in western North America. The paleobathymetry of most Desmoinesian fusulinids in Colorado was estimated at a range of 13-22 m with probable maximum depth of 30-40 m (Stevens, 1966, 1971). Ross (1968) also analyzed fusulinid paleobathymentric distibutions in Desmoinesian, Virgilian and Wolfcampian strata, and suggested that the average paleobathymentric range was 3-10 m, with a maximum depth of near 12-15 m. Thus, the fusulinid thermocline in North American tropical paleolatitude shelves is at least twice as shallow as in the tropical shelves in eastern Pangea (Fig. 4). These interpretations of paleobathymetric distributions suggest significantly cooler water paleoenvironments on paleotropical shelves of western Pangea , perhaps to the degree of the environments in the mid-latitudes (subtropics to temperate zones). 
Of course, this suggestion requires serious consideration, and it is could be potentially tested with several independent techniques.

Western Laurentian tropical fusulinacean assemblages are two to three times lower than that of the eastern shelves of Pangea (Urals, Donets Basins, Central Asia etc.) (Fig. 2). Even at higher latitudes, i.e. around mid_-latitudes in Arctic (Timan-Pechora, Spitsbergen and North Greenland) where the diversity usually low than in tropics, the diversity of SWWBF during Pennsylvanian was at least twice as high as in North American tropical shelves (Fig. 2). Besides this, North American realms that was within tropical paleolatitude never been a center of origination of the taxa that dispersed outside of the realm as it was occurring in Tethys. Rather the majory of the taxa in North American realm are highly endemic, i.e. dispersed only within the shelves of the western Laurentia. The SWWBF of North American realm commonly include genera that commonly occur only at higher temperate mid-latitudes in Boreal and Peri-Tethyan provinces (i.e. Pseudofusulinella, Wedekindellina, Eoparafusulina etc.). However, typical warm water taxa occasionally and abruptly occur throughout the Late Paleozoic in North America and potentially provide valuable information on the dynamics of Late Paleozoic climate (Ross, 1995; Davydov, 2008; Davydov et al., 2012; Wahlman, 2013). In particular, the record of warming episodes within the successions is highlighted by the occurrence of warmer water tropical taxa that are exotic to this region fauna. These warmer water and exotic for the region elements appear in the local communities suddenly due to migration during warming episodes and do not have any evolutionary roots with local faunas. It appears that most North American fusulinid faunas evolved elsewhere and episodically migrated into the region (Figs. 5-6).

It also make sense to assume that North American province was predominantly cool— water with permanent factor (s) controlling and keeping water cool (upwelling and/or cold water 
This is an author-produced, peer-reviewed version of this article. The final, definitive version of this document can be found online at

currents) . Global warming events will not affect North American shelves as much as the areas, where upwelling/or cold water currents are not significant, like in the Urals and Arctic, i.e. in mid-latitudal subtropics of Northern Pangea. In the latter regions though the global warming events increase the diversity so much that it is nearly reached the diversity in tropics (Davydov et al., 2014). At the same time the global cooling events will stronger affect Urals and Arctic regions and less significant North American province what will make climate more uniform between North American at tropical paleolatitude and northern Pangea subtropics (Arctic, Urals). This is consistent with the data from the recent foraminifera. As has been shown along the Western Australian coast the most pronounced changes of foraminifera diversity along the climate (temperature) gradient occur in summer, whereas during winter the foraminiferal assemblages along the gradient are more closely related (Semeniuk, 2001). Thus, during the warming events the greater diversity and taxonomic difference between permanently cooler North American shelves and Arctic-Urals shelves where climatic fluctuations were more dynamic might be expected. During the cooling events the difference between these regions perhaps was minimal.

\section{Late Paleozoic climate variation within the Western Pangea shelves}

At the very end of the Serpukhovian, North American shelves and Eastern Pangea share similar foraminiferal faunas even at species level. Several genera and important species such as Monotaxinoides subconicus (Brazhnikova and Yartseva), "Millerella" designata Zeller, "Millerella" tortula Zeller, Brenckleina rugosa (Brazhnikova), Eosigmoilina robertsoni (Brady), E. explicata Ganelina, , Eostaffella proikensis Rauser-Chernousova, Eolasiodiscus sp., Asteroarchaediscus rugosus (Rauser) are common in the latest Serpukhovian of Donets Basin 
and Urals and latest Chesterian (Kinkaid Limestone and Grove Church Shale) of North America (Brenckle, 1977; Brenckle et al., 2005). Recently, the earliest representative of the typical Tethyan genus Plectostaffella has been found in the uppermost Chesterian in the type sections in southern Illinois (Kulagina et al., 2008).

At the beginning of Bashkirian time, after the probable closure of Rheic pathway, the connection of western and eastern shelves of PangeaPangea was completely cutoff (Saltzman, 2003), which had adirect effect on the taxonomic composition of foraminifera faunas in the two regions. Provincialism of foraminifera rapidly increased subsequently and almost no common species occur in the western and eastern shelves of Pangea. Moreover, in the western Pangea (North American) shelves the taxonomic diversity of fusulinids decreased markedly compared to the eastern Pangea shelves (Fig. 2). The fusulinid diversity in North American shelves during the Morrowan, i.e. the major part of the Bashkirian, is the lowest within the entire Carboniferous and Permian. Two to three long — ranging species of Millerella and several rare species of Eostaffella occur in North American shelves during that time (Brenckle, 1977; Nodine-Zeller, 1977; Groves, 1986). The time correlative Bashkirian assemblages in Tethys include over 10 genera and 40-50 species (Brazhnikova et al., 1967; Vdovenko et al., 1984; Kulagina et al., 1992; Kulagina et al., 1997; Groves et al., 1999; ;). Only one genus, Millerella, is common in both the western and eastern shelves of Pangean regions. The genus appeared at the beginning of the Bashkirian or slightly earlier and became rapidly distributed globally. The occurrence of that genus in all know regions are isochronous (Vachard and Maslo, 1996; Groves et al., 1999). The low foraminiferal diversity during the Morrowan can be linked with the Bashkirian glacial event recently constrained in Gondwana (C2 glaciation) (Fielding et al., 2008a; Gulbranson et al., 2010). Because of slow evolution and extremely low diversity during the early and middle 
Bashkirian (Morrowan) time, no zonation has been established in the Morrowan of North America (Groves, 1986; Wahlman, 2013). The Morrowan was probably the coldest in the North American shelves environment lasting for about 4.5-5.0 Ma ( Fig. 5) (Davydov et al., 2012). Long—ranging $\mathrm{r}$ —-strategist Millerella was apparently one of the most environmentally tolerant fusulinid during early to middle Bashkiraian time and the global cooling event allowed its isochronous dispersal in both western and eastern temperate Pangea shelves.

The first warming episode in North American shelves at the beginning of the Atokan time was associated with the immigration of Pseudostaffella and slightly later Schubertella and Schubertina (Groves, 1986; Davydov, 2011). The Pseudostaffella FAD (First Appearance Datum) in eastern Pangea and elsewhere in Tethys is in lower Bashkirian, approximately at 321.5 Ma (Reitlinger, 1971; Kulagina and Sinitsyna, 2003; Davydov et al., 2012; ) and the FOD (First Occurrence Datum) of the genus in North America is about 318.5-318 Ma, i.e. with the delay of 2.0-3.0 Ma (Groves et al., 1999; Davydov et al., 2012). The Schubertella and Schubertina FAD in Tethys is at about middle Bashkirian (Kulagina et al., 2001; Nikolaev, 2005) and its migration to North America was not delayed as much as Pseudostaffella.

The second important immigration event, and possible warming episode, is associated with the occurrence of Profusulinella in the upper Atokan time (Groves et al., 1999) at the beginning of the global early Moscovian transgression (Makhlina et al., 2001; Schmitz and Davydov, 2012). The Profusulinella FAD in Tethys and Boreal provinces is at $320 \mathrm{Ma}$, compared with its FOD in North America at approximately 315 Ma (Davydov et al., 2012). The genus is widely distributed within the western shelves of Pangea and is well documented from Bolivia to the Great Basin and western Canada (McGugan and Rapson, 1979; Groves and Sanderson, 1990; Sakagami and Mizuno, 1994). The delay of the occurrence of Profusulinella in 
North America in respect to the FAD in Tethys was approximately 4.5-5.0 Ma (Fig. 5) (Davydov et al., 2012).

Two cooling events can be recognized within the Moscovian and the MoscovianKasimovian transition. The first one is marked by the sudden and isochronous occurrence of Wedekindellina in both North American and Arctic/Urals shelves. Wedekindellina is restricted only to these two areas and has not been reported from Tethys and/or Peri-Gondwana. In Boreal province, Wedekindellina is a very common form and is documented in Central and Northern Urals, Timan-Pechora and Spitsbergen-North Greenland and Canadian Arctic regions (Chuvashov and Dyupina, 1979; Rui Lin et al., 1991; Groves et al., 1994; Remizova, 1995; Davydov, 1997a; Davydov and Nilsson, 1999; Davydov et al., 2001; ). The southernmost occurrence of Wedekindellina in Boreal shelves is in the Southern Urals, where this genus is rare (Davydov, 1986). Wedekindellina is common in North American shelves where it occurs at the base Desmoinesian (Thompson, 1934; Waddell, 1966; Wahlman, 2013). The evolutionary roots of the genus are not clear. Most probably it is evolved from Fusulinella (Miklukho-Maclay et al., 1959). The first occurrence datum in both North American and Boreal shelves are well constrained and seem synchronous. This evolutionary event is also associated with the reduction of the fusulinid diversity in Podolskian in the eastern Pangaea and at the Atokan-Desmoinesian transition in the western Pangaea (Groves and Wang, 2009; Davydov et al., 2012) and increasing provincialism (Schmitz and Davydov, 2012). The isochronicity of the occurrence of Wedekindellina in temperate climatic zones (Arctic-Urals and North American shelves) is interpreted here as evidence of a cooling event where cool—water assemblages in both North America shelves and northern Pangea shelves become more uniform then the warm water assemblages in these regions (Fig. 5). The last occurrence datum of Wedekindellina in Timan- 
Pechora Basin is the middle Kasimovian (Remizova, 1995; Davydov, 1997a). In North America

Wedekindellina considered lower Desmoinesian genus (Thompson, 1954; Wahlman, 2013).

However, rare Wedekindellina ranged up to the top of Desmoinesian (personal data of the author from Nevada). The second potential cooling event corresponds with the major extinction event in the fusulinid evolution at the Moscovian-Kasimovian boundary (Kireeva, 1964; Reitlinger, 1969; Davydov, 1990; Davydov and Nilsson, 1999). This extinction is well expressed in Tethys (Leven and Davydov, 2001) and at the global scale (Groves and Wang, 2009; Davydov et al., 2012) and is associated with the unconformity in many regions in Pangaea (Davydov and Nilsson, 1999) and with the turnover of the early-middle Pennsylvanian fusulinellid fauna into the late Pennsylvanian-Permian schwagerinid fauna. In Boreal and North America provinces this event is marked by the occurrence Eowaeringella. At the boundary in the North America there is also a marked unconformity and an interval that lacks any significant fusulinids. Eowaeringella genus in North America characterizes the lowermost Missourian (Thompson et al., 1956; Stewart, 1968; Wahlman, 2013). In the Boreal region it is known to occur in the early to middle Kasimovian of Timan-Pechora (Remizova, 2004). These two occurrences essentially isochronous (Schmitz and Davydov, 2012) (Fig. 5). The genus range is very short.

Early-middle Kasimovian is also approximates with the first occurrence datum of a poorly known genus Oketaella in both North America and Timan-Pechora Basin. In the first region, it co-occurs with Eowaeringella and in Timan-Pechora it is reported from early to middle Kasimovian (Thompson et al., 1956; Remizova, 1995; Davydov, 1997a; Wahlman, 2013).The next warming event in the North American shelves is marked by the immigration of Triticites from Eurasia (Davydov, 1997b; Thompson, 1967; Villa and Wahlman, 2007). The genus evolved in Tethys during early to middle Kasimovian (late Desmoinesian-early Missourian) and 
appeared in North America only in the early middle Missourian (upper Kasimovian) (Davydov, 1997b; Thompson et al., 1956; Wahlman, 2013). The time lag in the appearrence of the genus in North America is 1.5-2.0 Ma (Fig. 5).

Another warming event during the late Gzhelian in the Tethyan and Boreal provinces is associated with the maximum peak in foraminiferal diversity and the global distribution of many fusulinid species (Groves and Wang, 2009; Davydov et al., 2012; Davydov, 2013; Davydov et al., 2013a; ). In North American shelves it is marked by the occurrence of Occidentoschwagerina (=Advenella of Wilde, 2006), Likharevites (= “Alpinoschwagerina” of Wilde, 2006) and Schellwienia, which is thought here to include many North American species traditionally placed in Schwagerina or Pseudofusulina. (Davydov et al., 2014 ).

Occidentoschwagerina, Likharevites and Schellwienia are exotic to the region, possess no evolutionary relationship with any local fusulinid faunas and are most likely migrated to the region from the Tethys. . Schellwienia in Tethys appears in the late Gzhelian Daixina sokensis zone (Davydov, 1986), whereas in North America the genus appears in the latest Gzhelian (Schmitz and Davydov, 2012; Wahlman, 2013). The difference between the occurrences in the Tethys and North American shelves is around 1 Ma or less (Fig. 5) suggesting a very rapid onset of global warming event at this time (Davydov et al., 2013a). This event is coincident with the highest global foraminiferal diversity during the Pennsylvanian-Permian time (Groves and Wang, 2009; Davydov et al., 2012).Occidentoschwagerina and Likharevites are typical Tethyan genera and in the Boreal province occur only in Spitsbergen and Central Urals (Nilsson and Davydov, 1997; Vilesov, 2000 ). In North America these genera are found only in New Mexico (Wilde, 2006). 
The proposed here global warming event contradicts with several recent papers that cite the maximum late Paleozoic glacial event around the Carboniferous-Permian boundary, i.e., Late Gzhelian (Montanez et al.,2007; Fielding et al., 2008b; Isbell et al., 2012) This contradiction definitely requires special attention and multidisciplinary studies. It can be noted, however, that the proposed here late Gzhelian global warming event are precisely constrained biostratigraphically whereas the direct record of glaciation over Carboniferous-Permian transition interval remains equivocal given the paucity of chronostratigraphic constraints (Montanez and Poulsen, 2013).

Middle Asselian appearance of Pseudoschwagerina, is well-documented in the Tethys (Scherbovich, 1949; Rauser-Chernousova, 1961; Bensh, 1972; Leven and Scherbovich, 1978; ). In the Boreal province and in North America it appeared during late Asselian time (Thompson, 1954; Konovalova, 1991; Nilsson and Davydov, 1997; Schmitz and Davydov, 2012;), which suggests a warming event at that time. There are several other lines of evidence of the warming event during late Asselian in the North American and Boreal shelves. For example, Biwaella, which appears in the Tethys in the early Gzhelian (Davydov, 2011), migrated into the Boreal province in the late Asselian (Nilsson and Davydov, 1997). The typical warm water fusulinid Sphaeroschwagerina first appears at the beginning of the Asselian in the Tethyan province (Scherbovich, 1949; Kireeva et al., 1971; Leven and Scherbovich, 1978;Davydov, 1984) occurs only in the late Asselian in Spitsbergen and Canadian Arctic (Rui Lin et al., 1994; Nilsson and Davydov, 1997;). Also during the late Asselian time, the species Pseudofusulina attenuata Skinner and Wilde from Klamath microcontinent migrated to the North American shelves, being reported in Nevada (Stevens et al., 1979; Davydov et al., 1997b;) and western Canada (ZubinStathopoulos et al., 2012). The difference in the occurrences of Pseudoschwagerina in Tethys 
and North America is minimal and does not exceed 1-1.5 Ma. Therefore, the late Asselian warming event was shorter and not as extensive as the late Gzhelian event as indicated by the overall lower foraminiferal diversity in the late Asselian (Groves and Wang, 2009; Davydov et al., 2012).

The widespread and isochronous occurrence of Eoparafusulina in Boreal and North American shelves at the beginning of Sakmarian perhaps indicates another cooling event. In Timan-Pechora and Spitsbergen this genus is very abundant in the earliest Sakmarian and becomes rare during middle Sakmarian (Grozdilova and Lebedeva, 1961; Nilsson and Davydov, 1997; Remizova, 1997). In North America, the earliest occurrence of Eoparafusulina is reported from the single horizon in the upper part of the Neal Ranch Formation in Glass Mountains, Texas (Ross, 1967), which correlates with early Sakmarian (Wardlaw and Davydov, 2000). The range of Eoparafusulina in Boreal province is very short, within the lower Sakmarian only (Remizova, 2004; Davydov, 1997a). In North America, Eoparafusulina occurs as two acmezones. The first one is in the early Sakmarian (Neal Ranch Formation in Glass Mountains) and it is restricted to Texas only. The second is in the latest Artinskian through early Kungurian in age and is widely known from Texas to Nevada (Dunbar and Skinner, 1937; Stevens et al., 1979; Davydov et al., 1997b). This second acme zone potentially might also represent the cooling event, but such a suggestion requires further evaluation. Eoparafusulina is also known from PeriGondwanan sections (Leven, 1993; Ueno, 2006; Davydov and Arefifard, 2013), where they occur in the assemblages with uncertain late Sakmarian to early Artinskian age.

The position and expression of the Late Sakmarian warming event in North American shelves is not clear. In the Urals and Arctic this event is associated with thick reef buildups (Rauser-Chernousova, 1950; Chuvashov, 1983; Rafaelsen et al., 2008) and significant 
transgression (Davydov et al., 1997a), but it cannot be readily recognized in the North American succession. It should be post-Nealian, early Lenoxian in age. However, early Lenoxian is already Artinskian in age as the upper Lenoxian possesses the late Artinskian fusulinid Chalaroschwagerina hawkinsi and conodont Neostreptognathodus transitus (Wardlaw and Davydov, 2000). Besides, the lower Lenoxian Perigondwania tersa (Ross) has been found recently in lower Artinskian of Carnic Alps (Davydov et al., 2013b). In summary, the recognition of this event in North American succession requires further studies.

A late Artinskian warming event in the North America temperate zone is associated with the occurrence of several genera. The most prominent genus is Chalaroschwagerina, which appears in Tethys in the middle Artinskian (Davydov et al., 2013b) and is widespread in Tethys and the Klamath microcontinents through the late Artinskian-Kungurian. It occurs in North American shelves in the late Artinskian (Ch. hawkinsi, Ch. nelsoni, Ch. solita) (Dunbar and Skinner, 1937; Davydov et al., 1997b; Stevens and Stone, 2009). The delayed occurrence of the genus in North America is about 2-2.5 Ma. Another typical Tethyan Sakmarian-Kungurian genus Robustoschwagerina has been documented from lower Kungurian (middle Leonardian) in Texas (Dunbar, 1953; Ross and Ross, 2009). Also, Biwaella and Rugosochusenella occur in the Gzhelian of Tethys (Davydov, 1986, 2011), but do not appear in the south of North America (New Mexico) until the upper Artinskian (Skinner and Wilde, 1965). Because of strong provincialism of North American fusulinid assemblages in Kungurian-Wordian and perhaps overall temperate climate at that time, no Tethyan elements have been reported, except for the occurrence of rare Yangchienia iniqua in the upper Kungurian part of the Road Canyon Formation (Yang and Yancey, 2000). The genus Yangchienia appeared in the Tethys in the early Kungurian (Leven et al., 1992). The late Kungurian in Tethys is characterized by a high 
fusulinid diversity peak within the Guadalupian (Figs. 1B and 4) and possibly with a warming episode. The time lag of the Yangchienia occurrences in Tethys and North America is about 44.5 Ma (Fig. 6).

The last prominent warming event and major fusulinid migration to North America occurred during the late Capitanian and included the Tethyan fusulinids such as Yabeina, Pseudokahlerina, Paradoxiella, Reichelina, Codonofusiella, Rauserella and Lanchichites. Also, the very characteristic Tethyan smaller foraminifera Abadehella has been found above the Yabeina in Texas (Dunbar and Skinner, 1937; Nestell et al., 2006; Skinner and Wilde, 1955).

The neoschwagerinid Yabeina is the most important taxon. Neoschwagerinids are a very climatically sensitive foraminifera that survive only in very warm paleoenvironments where surface water is thought to have exceeded an annual temperature of about 20-22 C (Ueno, 2006; Davydov and Arefifard, 2013). It seems the shallow-water paleoclimatic condition in Texas at the time was marginal for neoschwagerinids because Yabeina in the area is rare and is represented by only a small and primitive form. The rest of the fusulinids, most of which were schubertellids and ozawainellids, are more resistant to the temperate environments (Davydov, 2011) and are thus more diverse and abundant in the upper Capitanian in North America. Yabeina appear in Tethys sometime in late Wordian time (early Midian in Tethys) together with other diverse verbeekinds/neoschwagerinids and the schubertellids and ozawainellids mentioned above. In North America, Yabeina occurs with the time lag of about 4-4.5 Ma (Fig. 6).

\section{Western Pangea climate: Regional vs Global Signal?}

The observations made here regarding western Pangean paleoclimatic fluctuations are based on interpretations of fusulinid diversity patterns and migrations events. The parallel 
tracking of the provincial and global fusulinid generic diversity curves (Figure 1B) suggests that paleoclimatic and taxonomic trends were linked and global in nature. (Groves and Wang, 2009; Davydov et al., 2012). A very similar pattern has been documented at the species level when comparing global and North American foraminiferal diversity (Groves and Wang, 2009). Those parallel trends suggest that paleoclimatic events in the North American province were controlled primarily by global factors. Of course, this suggestion must be taken with great caution and evaluated further with different approaches and methods.

\section{Conclusions.}

The North American shelves during Pennsylvanian and Permian time were paleogeographically located in tropical paleolatitude, but appear to have had temperate paleoclimates as indicated by significantly lower foraminiferal diversity than correlative warmwater Tethyan faunas. The episodic appearances of Tethyan faunal elements on the North American shelves are interpreted to indicate paleoclimatic warming events, rising sealevels, and interregional migrations of taxa. Several warming and cooling events are identified . The magnitude of taxonomic changes in each event could potentially be used for provisionally estimating paleoclimatic variations. The occurrences of forms exotic to North America during warming episodes are always delayed in regards of their first appearances in Tethys. The duration of these delays was dependent the magnitude and intensity of the warming episodes.

The cooling events are associated with increasing provincialism, decreasing taxonomic diversity and appearances of endemic forms characteristic of temperate water provinces only. The occurrence of these forms in Boreal and North American provinces appears to be isochronous, probably because their environments were uniform. . The patterns of global and 
North American province diversity at generic and species levels are very similar. A strong link between biotic and climatic events in North American province and the similarity of biotic changes in the North American and other provinces suggests that paleoclimatic events in North American province were controlled by global factors.

\section{Acknowledgements.}

This paper was completed with support from NSF grants 014G106200 and 014G106225 and is also performed according to the Russian Government Program of Competitive Growth of Kazan Federal University. I thank Isabel Montanez, Mark Schmitz, Rimma Khodjanijazova, and waterm Snyder for the discussion of different aspects of late Paleozoic climate and tectonics of North America. The reviewers Prof. Calvin Stevens and Dr. Gregory Wahlman and the editor Prof. Finn Surlyk have made many critical suggestions that improved the manuscript.

\section{References sited.}

Afzal, J., Williams, M., Leng, M.J., Aldridge, R.J., 2011. Dynamic response of the shallow marine benthic ecosystem to regional and pan-Tethyan environmental change at the Paleocene-Eocene boundary. Palaeogeography, Palaeoclimatology, Palaeoecology 309, 141-160.

Baranova, D.V., Kabanov, P.B., 2003. Facies distribution of fusulinoid genera in the Myachkovian (Upper Carboniferous, upper Moscovian) of southern Moscow region. Rivista Italiana di Paleontologia e Stratigrafia 109, 225-239. 
Beavington-Penney, S.J., and Racey, A., 2004. Ecology of extant nummulitids and other larger benthic foraminifera: applications in paleoenvironmental analysis. Earth-Science Reviews 67, 219-265.

Beauchamp, B., 1994. Permian climatic cooling in the Canadian Arctic. Special Paper Geological Society of America 288, 229-246.

Bensh, F.R., 1972. Stratigrafiya i fuzulinidy verkhnego paleozoya Yuzhnoy Fergany. Stratigraphy and fusulinids of the upper Paleozoic of southern Fergana, in: RauserChernousova, D.M. (Ed.). Fan, Tashkent, pp. 1-149, (In Russian)

Bishop, J.W., Montanez, I., Poulsen, C.J., , 2007. Near-freezing low-latitude surface waters during Pennsylvanian glaciation; glendonites from equatorial western Pangea. Abstracts with Programs Geological Society of America. 39, 355.

Blakey, R.C., 2008. Gondwana paleogeography from assembly to breakup; a 500 m.y. odyssey. Special Paper Geological Society of America 441, 1-28.

Brazhnikova, N.E., Vakarchuk, G.I., Vdovenko, M.V., Vinnichenko, L.V., Karpova, M.A., Kolomiyets, Y.I., Potiyevskaya, P.D., Rostovtseva, L.F., Shevchenko, G.D., 1967. Mikrofaunisticheskiye markiruyushchiye gorizonty kamennougol'nykh i permskikh otlozheniy Dneprovsko-Donetskoy vpadiny. Microfaunal marker horizons in the Carboniferous and Permian deposits of the Dnieper-Donets basin. Akad. Nauk Ukr. SSR, Inst. Geol. Nauk, Kiev (In Russian).

Brenckle, P.L., 1977. Foraminifers and other calcareous microfossils from late Chesterian (Mississippian) strata of Northern Arkansas, in: Sutherland, P.K., Manger, W.L. (Eds.), Upper Chesterian-Morrowan stratigraphy and the Mississippian-Pennsylvanian boundary 
in North-eastern Oklahoma and North-Western Arkansas. Oklahoma Geological Survey Guidebook 18. The University of Oklahoma, pp. 73-88.

Brenckle, P.L., Lane, H.R., Heckel, P.H., Rankey, E.C., 2005. Stratigraphy and biostratigraphy of the Mississippian subsystem (Carboniferous system) in its type region, the Mississippi River valley of Illinois, Missouri, and Iowa; stop descriptions [modified]. Guidebook Series Illinois State Geological Survey, Report 34, 1-54.

Brezinski, D.K., Blaine, C., Skema, V.W., 2010. Late Devonian glacigenic and associated facies from the central Appalachian Basin, eastern United States. GSA Bulletin 122, 265-281.

Burrows, M.T., Schoeman, D.S., Buckley, L.B., Moore, P., Poloczanska, E.S., Brander, K.M., Brown, C., Bruno, J.F., Duarte, C.M., Halpern, B.S., Holding, J., Kappel, C.V., Kiessling, W., O’Connor, M.I., Pandolfi, J.M., Parmesan, c., Schwing, F.B., Sydeman, W.J., Richardson, A.J., 2011. The Pace of Shifting Climate in Marine and Terrestrial Ecosystems. Science 334 (6056), 652-655.

Buzas, M.A., Collins, L.S., Culver, S.J., 2002. Latitudinal difference in biodiversity caused by higher tropical rate of increase. Proceedings of the National Academy of Sciences of the United States of America 99, 7841-7843.

Chuvashov, B.I., 1983. Permian reefs of the Urals. Facies 8, 191-212.

Chuvashov, B.I., Dyupina, G.V., 1979. Stratigrafiya i fatsii verkhnego karbona zapadnogo sklona Srednego Urala. Stratigraphy and facial zones of the Carboniferous deposits of the western Urals. Compte Rendu Congres International de Stratigraphie et de Geologie du Carbonifere = International Congress on Carboniferous Stratigraphy and Geology., no. 2, 257-262. 
Clapham, M.E., 2010. Faunal evidence for a cool boundary current and decoupled regional climate cooling in the Permian of western Laurentia. Palaeogeography, Palaeocimatology and Palaeogeography 298, 348-359.

Davydov, V.I., 1984. On the problem of origin of Schwagerins. Paleontological. Journal, 3-16. (In Russian.).

Davydov, V.I., 1986. Upper Carboniferous and Asselian fusulinids of the Southern Urals, in: Chuvashov, E.Y.L.a.V.I.D. (Ed.), Carboniferous-Permian Boundary beds of the Urals, Pre-Urals and Central Asia. Nauka Publishing House, Moscow, pp. 77-103 (In Russian)

Davydov, V.I., 1990. Clarification of the origin and phylogeny of triticitids and of the Middle/ Upper Carboniferous boundary. Paleontological Journal 24, 13-25 (In Russian.) Translation in Scripta Technica, Inc. 1991, p. 1939-1951 (In English).

Davydov, V.I., 1997a. Fusulinid biostratigraphy of the Upper Paleozoic of the Kolguev Island and Franz Josef Land Archipelago., in: Belonin, M.D., Kirichkova, A.I. and Kozlova, G.E (Ed.), Biostratigraphy of the oil-bearing basins. Transactions of First International symposium. VNIGRI, St. Petersburg, pp. 40-59. (In Russian.).

Davydov, V.I., 1997b. Middle/Upper Carboniferous Boundary: the problem of definition and correlation, in: M. Podemski, S.D., J., J. Jureczka and R. Wagner (eds.), Proceeding of the XIII International Congress on the Carboniferous and Permian, Warszawa, pp. 113122.

Davydov, V., 2008. Late Paleozoic climate: constraints on warming and cooling from the benthic Foraminifera record. Abstracts with Programs, Geological Society of America 40, p.401. Davydov, V.I., 2011. Taxonomy, nomenclature and evolution of the early schubertellids (Fusulinida, Foraminifera) Acta Palaeontologica Polonica. 56, 181-194. 
Davydov, V.I., 2013. Climate Fluctuations within the Western Pangean Tropical Shelves - The Pennsylvanian/ Permian record from Benthic Foraminifera, in: Lucas, S.G., Schneider, J.W., J.A., S. (Eds.), The Carboniferous-Permian Transition. Bulletin. New Mexico Museum of Natural History and Science, New Mexico Museum of Natural History and Science, pp. 73-78.

Davydov, V.I., Arefifard, S., 2007. Permian Fusulinid Fauna of Gondwanan Affinity from Kalmard Region, East-Central Iran and its Significance for the Tectonics and Paleogeography, Paleontologia electronica, http://palaeo-electronica.org/ 2007_2 /00124/ index.html, p. 40 p.

Davydov, V.I., Arefifard, S., 2013. Middle Permian (Guadalupian) fusulinid taxonomy and biostratigraphy of the mid-latitude Dalan Basin, Zagros, Iran and their applications in paleoclimate dynamics and paleogeography. Geoarabia 18, 17-62.

Davydov, V.I., Haig, D.W., Mccartain, E., 2013. A latest Carboniferous warming spike recorded by a fusulinid — rich bioherm in Timor Leste: Implications for East Gondwana deglaciation. Palaeogeography, Palaeocimatology and Palaeogeography 376 22-38.

Davydov, V.I., Haig, D.W., McCartain, E., 2014. Latest Carboniferous (late Gzhelian) fusulinids from Timor Leste and their paleobiogeographic affinities. Journal of Paleontology 88, 588-605.

Davydov, V.I., Korn, D., Schmitz, M.D., 2012. The Carboniferous Period, in: Gradstein, F.M., Ogg, J.G., Schmitz, M.D., Ogg, G. (Eds.), The Geologic Time Scale 2012. Elsevier, Amsterdam, pp. 603-651. 
Davydov, V.I., Krainer, K., Chernykh, V.V., 2013b. Fusulinid biostratigraphy of the Lower Permian Zweikofel Formation (Rattendorf Group; Carnic Alps, Austria) and Lower Permian Tethyan chronostratigraphy. Geological Journal 48, 57-100

Davydov, V.I., Nilsson, I., 1999. Fusulinids in the Middle Upper Carboniferous Boundary Beds on Spitsbergen, Arctic Norway. Palaeontologia Electronica, http://paleo-electronica.org 2, 45 pp.

Davydov, V.I., Nilsson, I., Stemmerik, L., 2001. Fusulinid zonation of the Upper Carboniferous Kap Jungersen and Foldedal Formations, southern Amdrup Land, eastern north Greenland. Bulletin of the Geological Society of Denmark 48, 31-77.

Davydov, V.I., Snyder, W.S., Spinosa, C., 1997a. Fusulinacean biostratigraphy and sequence stratigraphy of the upper Paleozoic of the Southern Urals. Special Publications Cushman Foundation for Foraminiferal Research 36, 27-30.

Davydov, V.I., Snyder, W.S., Spinosa, C., 1997b. Permian foraminiferal biostratigraphy and sequence stratigraphy of Nevada. Special Publications - Cushman Foundation for Foraminiferal Research 36, 31-34.

Dunbar, C.O., 1953. A zone of Pseudoschwagerina low in the Leonard Series in the Sierra Diablo, Trans-Pecos Texas. American Journal of Science 251, 798-813.

Dunbar, C.O., Skinner, J.W., 1937. Permian Fusulinidae of Texas. University of Texas Bulletin, Report 3701, 517-825.

Fielding, C.R., Frank, T.D., Birgenheier, L.P., Rygel, M.C., Jones, A.T., Roberts, J., 2008a. Stratigraphic record and facies associations of the late Paleozoic ice age in eastern Australia (New South Wales and Queensland). Special Paper - Geological Society of America 441, 41-57. 
Fielding, C.R., Frank, T.D., Isbell, J.L., 2008b. The late Paleozoic ice age; a review of current understanding and synthesis of global climate patterns. Special Paper - Geological Society of America 441, 343-354.

Fuhrman, J.A., Steele, J.A., Hewson, I., Schwalbach, M.S., Brown, M.V., Green, J.L., Brown, J.H., 2008. A latitudinal diversity gradient in planktonic marine bacteria. PNAS 105, 7774-7778

Groves, J.R., 1986. Foraminiferal characterization of the Morrowan-Atokan (lower Middle Pennsylvanian) boundary. Geological Society of America Bulletin 97, 346-353.

Groves, J.R., Nassichuk, W.W., Lin, R., Pinard, S., 1994. Middle Carboniferous Fusulinacean biostratigraphy, northern Ellesmere Island (Sverdrup Basin, Canadian Arctic Archipelago). Bulletin Geological Survey of Canada, Report 469, 55 p. .

Groves, J.R., Nemyrovska, T.I., Alekseev, A.S., 1999. Correlation of the type Bashkirian Stage (Middle Carboniferous, South Urals) with the Morrowan and Atokan series of the Midcontinental and Western United States. Journal of Paleontology 73, 529-539.

Groves, J.R., Sanderson, G.A., 1990. Systematics of the North American species of Profusulinella (Middle Pennsylvanian Fusulinidae). Micropaleontology 36, 105-140.

Groves, J.R., Wang, Y., 2009. Foraminiferal diversification during the late Paleozoic ice age. Paleobiology 35, 367-392.

Grozdilova, L.P., Lebedeva, N.S., 1961. Lower Permian foraminifers of North Timan, in: anonimmous (Ed.), Transactions of VNIGRI, 179, 161-283 (In Russian).

Gulbranson, E.L., Montanez, I.P., Schmitz, M.D., Limarino, C.O., Isbell, J.L., Marenssi, S.A., Crowley, J.L., 2010. High—resolution U-Pb calibration of Carboniferous glacigenic 
deposits, Rio Blanco and Paganzo basins, northwest Argentina. Geological Society of America Bulletin 122, 1480-1498.

Hallock, P., Premoli Silva, I., Boersma, A., 1991. Similarities between planktonic and larger foraminiferal evolutionary trends through Paleogene paleoceanographic changes. Palaeogeography, Palaeoclimatology, Palaeoecology 83, 49-64.

Hanken, N.-M., Nielsen, J.K., 2013. Upper Carboniferous-Lower Permian Palaeoaplysina build — ups on Svalbard; the influence of climate, salinity and sea — level. Special Publication - Geological Society of London 376, 269-305.

Hohenegger, J., 2004. Depth coenoclines and environmental considerations of western Pacific larger Foraminifera. Journal of Foraminiferal Research 34, 9-33.

Huston, M.A., 1994. Biological Diversity: The Coexistence of Species. Cambridge University Press.

Isbell, J.L., Henry, L.C., Gulbranson, E.L., Limarino, C.O., Fraiser, M.L., Koch, Z.J., Ciccioli, P.L., Dineen, A.A., 2012. Glacial paradoxes during the late Paleozoic ice age; evaluating the equilibrium line altitude as a control on glaciation. Gondwana Research 22, 1-19.

Isbell, J.L., Lenaker, P.A., Askin, R.A., Miller, M.F., Babcock, L.E., 2003. Reevaluation of the timing and extent of late Paleozoic glaciation in Gondwana; role of the Transantarctic Mountains. Geology 31, 977-980.

Jablonski, D., Roy, K., Valentine, J.W., 2006. Out of the Tropics: Evolutionary Dynamics of the Latitudinal Diversity Gradient. SCIENCE 314, 102-106.

Kalvoda, J., 2002. Late Devonian-Early Carboniferous Foraminiferal Fauna: Zonations, Evolutionary events, paleobiogeography and tectonic implications. Masaryk University, Brno, Czech Republic,. 
Kauffman, E.G., Runnegar, B., 1975. Atomodesma (Bivalvia), and Permian Species of the United States. Journal of Paleontology 49, 23-51.

Khodjanyazova, R., Davydov, V., Montaez, I., Schmitz, M., 2014,. Climate — and eustasy— driven cyclicity in Pennsylvanian fusulinid 6 assemblages, Donets Basin (Ukraine). Palaeogeography, Palaeocimatology and Palaeogeography, 396, 41-46..

Kireeva, G.D., 1964. Taxonomical analyses of the wall structure of some fusulinids within the Moscovian-Kasimovian transition. Problems of micropaleontology., 53-56 (In Russian). Kireeva, G.D., Scherbovich, S.F., Dobrokhotova, S.V., Ketat, O.B., Malkovsky, F.S., Semina, S.A., Chernova, I.A., Yagofarova, F.Z., 1971. Schwagerina vulgaris and Schwagerina fusiformis zone of the Asselian Stage of the Russian Platform and the western slope of the southern Urals. Questions of micropaleonotlogy, 70-102. (In Russian).

Konovalova, M.V., 1991. Stratigraphy and fusulinids of Upper Carboniferous and Lower Permian of Timan-Pechora oil_— and gas_-bearing province. Nedra Publishing House, Moscow (In Russian).

Kulagina, E.I., Gibshman, N.B., Nikolaeva, S.V., 2008. Foraminifer-based correlation of the Chesterian Stage in the Mississippian type region, Illinois, USA with the Serpukhovian Stage of Russia. Newsletters on Carboniferous Stratigraphy 26, 14-18.

Kulagina, E.I., Pazukhin, V.N., Kochetkova, N.M., Synytsina, Z.A., Kochetova, N.N., 2001. The type and the key sections of Bashkirian Stage of Carboniferous in Southern Urals. . Gilem Publishing House, Ufa (In Russian).

Kulagina, E.I., Rumjantseva, Z.S., Pazukhin, B.N., Kochetova, N.N., 1992. The midCarboniferous boundary in Southern Urals and Middle Tian-Shan'. Nauka, Moscow (In Russian). 
Kulagina, E.I., Sinitsyna, Z.A., 2003. Evolution of the Pseudostaffellidae in the Bashkirian Stage (Middle Carboniferous). Rivista Italiana di Paleontologia e Stratigrafia 109, 213-224.

Kulagina, E.I., Sinitsyna, Z.A., Ross, C.A., Ross, J.R.P., Brenckle, P.L., 1997. Foraminiferal zonation of the lower Bashkirian in the Askyn Section, South Urals, Russia. Special Publications Cushman Foundation for Foraminiferal Research 36, 83-88.

Leven, E.J., Davydov, V.I., 2001. Stratigraphy and fusulinids of the Kasimovian and lower Gzhelian (Upper Carboniferous) in the southwestern Darvaz (Pamir). Rivista Italiana di Paleontologia e Stratigrafia 107, 3-45.

Leven, E.Y., Leonova, T.B., Dmitriyev, V.Y., 1992. Perm Darvaz-Zaalaiskoi zony Pamira (fusulinidy, ammonoidei, stratigraphiya). The Permian of Darvas-Zaalai zone of Pamirs (fusulinids, ammonoids, stratigraphy) (In Russian).

Leven, E.Y., Scherbovich, S.F., 1978. Fuzulinidy i stratigrafiya assel'skogo yarusa Darvaza. Fusulinids and stratigraphy of the Asselian Stage of the Darvaz Range. Nauka, Moscow (n Russian).

Makhlina, M.K., Alekseyev, A.S., Goreva, N.V., Isakova, T.N., Drutskoy, S.N., 2001. Sredniy karbon Moskovskoy sineklizy (yuzhnaya chast'); v 2 tomakh; Tom 1, Stratigrafiya. Middle Carboniferous of southern Moscow Syneclise; Volume 1, Stratigraphy. Rossiyskaya Akademiya Nauk, Paleontologicheskiy Institut Moscow, (In Russian).

Mamet, B., 1977. Foraminiferal zonation of the Lower Carboniferous; methods and stratigraphic implications. Dowden, Hutchinson, and Ross, Stroudsburg, PA.

Mayhew, P.J., Bell, M.A., Benton, T.G., McGowan, A.J., 2012. Biodiversity tracks temperature over time. PNAS 109, 15141-15145. 
McGugan, A., Rapson, J.E., 1979. Pennsylvanian and Permian biostratigraphy, micropaleontology, petrography and diagenesis, Kananaskis Valley, Alberta. Bulletin of Canadien Petroleum Geolog 27, 405-417.

Meldon, E.A., Shi, G.R., 2003. Global Distribution of Permian Conulariids and Palaeobiogeographical Implications. Gondwana Research 6, 791-802.

Miklukho-Maclay, A.D., Rauser-Chernousova, D.M.a., Rosovskaya, S.E., 1959. Fusulinida Order, in: Rauser-Chernousova, D.M., and , Fursenko, A.V. (Eds.), Fundamentals of Paleontology. Protozoa,, pp. 201-215 (In Russian).

Montanez, I.P., Tabor, N.J., Niemeier, D., DiMichele, W.A., Frank, T.D., Fielding, C.R., Isbell, J.L., Birgenheier, L.P., Rygel, M.C., 2007. CO (sub 2) —forced climate and vegetation instability during late Paleozoic deglaciation. Science 315, 87-91.

Montanez, I.P., Poulsen, C.J., 2013. The late Paleozoic ice age; an evolving paradigm. Annual Review of Earth and Planetary Sciences 41, 629-656.

Murray, J., 2006. Ecology and Applications of Benthic Foraminifera. . Cambridge University Press, Cambridge, New York, Melbourne:.

Nassichuk, W.W., Wilde, G.L., 1977. Permian fusulinaceans and stratigraphy at Blind Fiord, southwestern Ellesmere Island. Bulletin - Geological Survey of Canada 268, 1-60.

Nestell, M.K., Nestell, G. P., Wardlaw, B.R., Sweatt, M.J., 2006. Integrated biostratigraphy of foraminifers, radiolarians and conodonts in shallow and deep water Middle Permian (Capitanian) deposits of the "Rader slide", Guadalupe Mountains, West Texas. . Stratigraphy 3, 161-194. 
Nikolaev, A.I., 2005. Foraminifers and zonal stratigraphy of Bashkirian Stage in the east of Timan-Pechora province. . Bulletin of paleontological and collections of VNIGRI, 120 p. (In Russian).

Nilsson, I., Davydov, V.I., 1997. Fusulinid biostratigraphy in Upper Carboniferous (Gzhelian) and Lower Permian (Asselian-Sakmarian) succession in Spitsbergen, Arctic Norway. Permophiles, 18-27.

Nodine-Zeller, D.E., 1977. Microfauna from Chesterian (Mississippian) and Morrowan (Pennsylvanian) rocks in Washington County, Arkansas, and Adair and Muskogee counties, Oklahoma. Guidebook - Oklahoma Geological Survey, 89-99.

Ozawa, T., 1987. Permian fusulinacean biogeographic provinces in Asia and their tectonic implications. Terra Sci. Publ. Co., Tokyo.

Perez-Huerta, A., 2007. First record of post—middle Desmoinesian (Late Carboniferous) brachiopods in the Great Basin (USA); implications for faunal migration in response to late Paleozoic paleogeography. Journal of Paleontology 81, 312-330.

Rafaelsen, B., Elvebakk, G., Andreassen, K., Stemmerik, L., Colpaert, A., Samuelsberg, T.J., 2008. From detached to attached carbonate buildup complexes - 3D seismic data from the upper Palaeozoic, Finnmark Platform, southwestern Barents Sea. Sedimentary Geology 206, 17-32.

Rauser-Chernousova, D.M., 1950. Fatsii verkhnekamennougolnykh i artinskikh otlozhenii Sterlitamaksko-Ishimbaiskogo Priuralya (na osnove izucheniya fuzulinid). Trudy Geologicheskiy Institut, Akademiya Nauk SSSR 119, 1-108 (in Russian). 
Rauser-Chernousova, D.M., 1961. Reviziya shvagerin s blizkimi rodami i granitsa karbona i permi. The revision of Schwagerina and related genera and the Carboniferous-Permian boundary. . Voprosy micropaleontologii, 3-32 (In Russian).

Rauser-Chernousova, D.M., Bensh, F.R., Vdovenko, M.V., Gibshman, N.B., Leven, E.Y., Lipinia, O.A., Reitlinger, E.A., Solovieva, M.N., Chediya, I.O., 1996. Sprovochnik po sistematike foramininfer Paleozoya (endothyroidi, fusulinoidi). The guide on the systematic of Paleozoic foraminifera (endothyroids and fusulinids). Nauka, Moscow.

Reitlinger, E.A., 1969. The evolution of foraminifera and its significance for the Carboniferous stratigraphy. Voprosy Mikropaleontologii, 3-33 (In Russian).

Reitlinger, E.A., 1971. Some problems of systematics in the light of evolutions of the Upper

Paleozoic foraminifera. Questions of micropaleonotlogy 14, 3-16 (In Russian).

Remizova, S.T., 1995. Foraminifers and biostratigraphy of Upper Carboniferous of the Northern Timan, Syktyvkar (In Russian).

Remizova, S.T., 1997. Fusulinids and stratigraphy of the Sakmarian Stage in the northern Timan. Prace Panstwowego Instytutu Geologicznego (1988) 157, 329-338.

Remizova, S.T., 2004. Fusulinoids of Timan: evolution, biostratigraphy and paleobiogeography. . Russian Academy of Sciences, Ekaterinburg (In Russian).

Ross, C.A., 1967. Eoparafusulina from the Neal Ranch Formation (Lower Permian), west Texas. Journal of Paleontology 41, 943-946.

Ross, C.A., 1968. Paleoecology of fusulinaceans. Academia, Czechoslovakia, Prague.

Ross, C.A., 1982. Paleobiology of fusulinaceans. Proceedings - North American Paleontological Convention 3, 441-445. 
Ross, C.A., 1995. Permian fusulinaceans, in: Scholle, P., Peryt, T.M., Ulmer-Scholle, D.S. (Eds.), The Permian of Northern Pangaea , pp. 167-185.

Ross, C.A., 1995. Permian fusulinaceans, in: Scholle, P.A., Peryt, T.M., Ulmer-Scholle, D.S. (Eds.), Permian of Northern Pangea. Vol. 1: Paleogeography, Paleoclimate, Stratigraphy. Springer-Verlag, Berlin, pp. 167-185.

Ross, C.A., Ross, J.R.P., 2009. Paleontology, a tool to resolve late paleozoic structural and depositional histories, in: Gary, T.D.D.a.A.C. (Ed.), Geologic Problem Solving with Microfossils: A Volume in Honor of Garry D. Jones. SEPM Special Publication pp. 95109.

Rui Lin, Nassichuk, W.W., Thorsteinsson, R., 1994. The Lower Permian Fusulinacean Sphaeroschwagerina in the Sverdrup Basin, Canadian Arctic Archipelago. Pangea: Global Environments and Resources, 891-905.

Rui Lin, Ross, C.A., Nassichuk, W.W., 1991. Upper Moscovian (Desmoinesian) Fusulinaceans from the type section of the Nansen Formation, Ellesmere Island (Sverdrup Basin, Canadian Arctic Archipelago). Bulletin Geological Survey of Canada, no 418, 121 p. .

Sakagami, S., Mizuno, Y., 1994. Discovery of Middle Pennsylvanian fusulinaceans and conodonts from the Copacabana Group in the Lake Titicaca region, Bolivia. Transactions and Proceedings of the Paleontological Society of Japan. New Series 174, 484-494.

Saltzman, M.R., 2003. Late Paleozoic ice age; oceanic gateway or pCO (sub 2) ? Geology 31, 151-154.

Scherbovich, S.F., 1949. (Part 2). Schwagerins, in: S.F. Scherbovich and , D.M. RauserChernousova (Eds.), Schwagerins of European part of U.S.S.R. Transactions of Institute of Geological Sciences, pp. 77-103, (In Russian). 
Schmitz, M.D., Davydov, V.I., 2012. Quantitative radiometric and biostratigraphic calibration of the Pennsylvanian - Early Permian (Cisuralian) time scale, and pan-Euramerican chronostratigraphic correlation. GSA Bulletin. GSA Bulletin 124, 549-577.

Semeniuk, T.A., 2001. Epiphytic Foraminifera along a climatic gradient, Western Australia. Journal of Foraminiferal Research 31, 191-200.

Skinner, J.W., Wilde, G.L., 1955. New fusulinids from the Permian of West Texas. Journal of Paleontology 29, 927-940.

Skinner, J.W., Wilde, G.L., 1965. Lower permian (wolfcampian) fusulinids from the big hatchet mountains, southwestern new mexico. Contributions from the Cushman Foundation for Foraminiferal Research 16, Part 3, 95-104.

Soreghan, G.S., Soreghan, M.J., Poulsen, C.J., Young, R.A., Eble, C.F., Sweet, D.E., Davogustto, O.C., 2008. Anomalous cold in the Pangean tropics. Geology 36, 659-662.

Stanley, S.M., 1984. Temperature and biotic crises in the marine realm. Geology 12, 205-208.

Stevens, C.H., 1966. Paleoecologic implications of early Permian fossil communities in eastern Nevada and western Utah. Geological Society of America Bulletin 77, 1121-1129.

Stevens, C.H., 1971. Distribution and diversity of Pennsylvanian marine faunas relative to water depth and distance from shore. Lethaia 4, 403-412.

Stevens, C.H., Wagner, D.B., Sumsion, S.R., 1979. Permian Fusulinid Biostratigraphy, Central Cordilleran Miogeosyncline. Journal of Paleontology 53, 29-36.

Stevens, C.H., Stone, P., 2009. New Permian fusulinids from Conglomerate Mesa, southeastern Inyo Mountains, east-central California. Journal of Paleontology 83, 9-29. 
This is an author-produced, peer-reviewed version of this article. The final, definitive version of this document can be found online at Palaeogeography, Palaeoclimatology, Palaeoecology, published by Elsevier. Copyright restrictions may apply. doi: 10.1016/ j.palaeo.2014.09.013

Stewart, W.J., 1968. The stratigraphic and phylogenetic significance of the fusulinid genus Eowaeringella, with several new species. Special Publications - Cushman Foundation for Foraminiferal Research 10, 29 pp.

Thompson, M.L., 1934. The fusulinids of the Des Moines series of Iowa. University of Iowa Studies in Natural History (1918) 16, 277-332.

Thompson, M.L., 1954. American Wolfcampian fusulinids. University of Kansas Paleontological Contributions Protozoa, art. 5, 1-225.

Thompson, M.L., 1967. American fusulinacean faunas containing elements from other continents. Essays in paleontology and stratigraphy - R. C. Moore Commemorative Volume, 102-112.

Thompson, M.L., Verville, G.J., Lokke, D.H., 1956. Fusulinids of the Desmoinesian-Missourian contact. Journal of Paleontology 30, 793-810.

Ueno, K., 2006. The Permian antitropical fusulinoidean genus Monodiexodina; distribution, taxonomy, paleobiogeography and paleoecology. Journal of Asian Earth Sciences 26, 380-404.

Vachard, D., Maslo, A., 1996. Precisions biostratigraphiques et micropaleontologiques sur le Bashkirien d'Ukraine (Carbonifere moyen). Biostratigraphical and micropaleontological data about the Ukrainian Bashkirian, Middle Carboniferous. Revue de Paleobiologie 15, 357-383.

Vachard, D., Munnecke, A., Servais, T., 2004. New SEM observations of keriothecal walls; implications for the evolution of Fusulinida. Journal of Foraminiferal Research 34, 232242. 
Vdovenko, M.V., Aizenverg, D.Y., Astakhova, T.V., Berchenko, O.I., Brazhnikova, N.Y., Gorak, S.V., Kozitskaya, R.I., Lipnyagov, O.M., Nemirovskaya, T.I., Novik, Y.O., Poletayev, V., Sergeyeva, M.T., Shchegolev, A.K., Vasiliuk, N.P., Ionosova, A.K., Shvartsman, Y.G., Kireyeva, G.D., Pogrebnyak, V.A., Teteryuk, B.K., Fisunenko, O.P., 1984. Zonal stratigraphical schemes of the Donetsk Basin Carboniferous. International Geological Congress, Abstracts = Congres Geologique International, Resumes 27, 200201.

Vdovenko, M.V., Rauser-Chernousova, D.M., Reitlinger, E.A., Sabirov, A., 1993. Spravochnik po sistematike melkikh Foramininfer paleozoya (za isklyucheniem endotiroroidei i permskikh rnnogokamemykh lagenoidei); [Reference on systematics of small Paleozoic foraminifera (with theexception of the endothyroids and Permian multichambered lagenoids)]: Trudy, Geological Institute, Russian Academy of Sciences, Commission of Micropaleontology. . Nauka, Moscow (In Russian).

Villa, E., Wahlman, G.P., 2007. Late middle to late Pennsylvanian fusulinoidean paleobiogeography, in: Wong, T.E. (Ed.), Proceedings of the XVth International Congress on Carboniferous and Permian stratigraphy. Royal Netherlands Academy of Arts and Sciences, 497-511.

Vilesov, A.P., 2000. Fusulinid-Based Zonation of the Melekhov Horizon (Upper Carboniferous, Gzhelian Stage) in the Perm' Region. Stratigraphy, Geological Correlations 8, 447-460.

Waddell, D.E., 1966. Pennsylvanian fusulinids in the Ardmore Basin, Love and Carter counties, Oklahoma. Bulletin - Oklahoma Geological Survey, 128. 
Wahlman, G.P., 2013. Pennsylvanian to Lower Permian (Desmoinesian-Wolfcampian) fusulinid biostratigraphy of Midcontinent North America. Stratigraphy, vol. 10, nos. 1-2, pp. 73104.

Wahlman, G.P., Konovalova, M.V., 2002. Upper Carboniferous-Lower Permian Kozhim carbonate bank, subpolar Pre—Ural Mountains, northern Russia. Special Publication Society for Sedimentary Geology 74, 219-241.

Wahlman, G.P., Verville, G.J., Sanderson, G.A., Ross, C.A., Ross, J.R.P., Brenckle, P.L., 1997. Biostratigraphic significance of the fusulinacean Protriticites in the Desmoinesian (Pennsylvanian) of the Rocky Mountains, Western U.S.A. Special Publications Cushman Foundation for Foraminiferal Research 36, 163-168.

Wardlaw, B.R., Davydov, V.I., 2000. Preliminary placement of the International Lower Permian Working Standard to the Glass Mountains, Texas. Permophiles 36, 10-13.

Weldon, E.A., Shi, G.R., 2003. Global distribution of Permian conulariids and palaeobiogeographical implications. Gondwana Research 6, 791-802.

Wilde, G.L., 2006. Pennsylvanian-Permian Fusulinaceans of the Big Hatchet Mountains, New Mexico. .

Winguth, A.M.E., Heinze, C., Kutzbach, J.E., Maier-Reimer, E., Mikolajewicz, U., Rowley, D., Rees, A., Ziegler, A.M., 2002. Simulated warm polar currents during the Middle Permian. Paleoceanography 17(4), 9-18.

Yang, Z., Yancey, T.E., 2000. Fusulinid biostratigraphy and paleontology of the Middle Permian (Guadalupian) strata of the Glass Mountains and Del Norte Mountains, West Texas. , in: Wardlaw, B.R., Grant, R.E., Rohr, D.M. (Eds.), The Guadalupian symposium. 
Smithsonian contribution to the Earth Sciences. Number 32. Smithsonian Institution, Washington, DC, Washington D.C., pp. 185-260.

Zachos, J., Pagani, M., Sloan, L., Thomas, E., Billups, K., Smith, J., Uppenbrink, J., 2001.

Trends, rhythms, and aberrations in global climate 65 Ma to present. Science 292, 686693.

Zubin-Stathopoulos, K.D., Beauchamp, B., Davydov, V.I., Henderson, C.M., 2012. Variability of Pennsylvanian-Permian Carbonate Associations and implications for NW Pangea Palaeogeography, east-central British Columbia, Canada. Geological Society, London, Special Publications 376, 47-72.

\section{FIGURES CAPTURE.}

Fig. 1. Distribution of warm — and temperate water environments during PennslvanianCisuralian. The reconstruction is simplified after Ziegler et al. (1997). NA — North American province, B — Boreal, P — Peri — Gondwana and T — Tethyan provinces. Black lines — cold current, yellow lines — warm currents. Black dotted line — approximate border between warm and temperate paleoclimatic zones

Fig. 2. Fusulinids generic global and provincial diversity pattern (the raw data from RauserChernousova et al., 1996). The foraminiferal diversity at the tropical paleolatitude in the North America shelves two-three times lower compare with those in Tethys province and even in mid - latitudal Boreal province. The maximum diversity peaks are generally corresponds with global warming episodes, whereas the minimal diversity peaks perhaps indicate the cooling events. Some of the proposed cooling events coincided with known global glacial episodes (blue stars) documented in the literature (Fielding et al., 2008b; Grossman et al., 2008; Gulbranson et 
al., 2010; Isbell et al., 2012). Note a very low diversity of endemic genera in North American province through the time. For more details see the text.

Fig. 3. Fundamental depth distributions of presen—-day northwest Pacific symbiont—bearing benthic warm water foraminifera in clear ocean water (developed from Hohenegger, 2004). The low limit of the thermocline for these foraminifera is at $140 \mathrm{~m}$. Foraminifera become abundant (> 50 species) at depth 110-100 m and reached their diversity/abundance at depth $40-30 \mathrm{~m}$.

Fig. 4. Distribution of shallow warm water benthic foraminifera at different latitudinal and paleoclimatic settings. A —idealized distribution of major recent foraminiferal groups in reefassociated environments in tropics (from Beavington-Penney and Racey, 2004), shallow warm water benthic foraminifera thermocline is going to 90-100 m depth; B —Distribution of fusulinid groups in Myachkovian (Late Moscovian) facies/environments in shallow-water carbonate subtropical $\left(25-30^{\circ} \mathrm{N}\right)$ environments in Russian Platform. Gray bars indicate abundance of fusulinids in different bathymetry/facies expressed as a number of specimens in square cm in thin — section. Fusulinids in this mid — latitude, transitional from tropics to subtropics region, distributed down to the depth 60-70 m (modified from Baranova and Kabanov, 2003); C reconstruction of depositional environments of the Pennsylvanian and Cisuralian at tropical paleolatitude carbonate shelves (western Pangea tropics) in Texas and distribution of species of fusulinids (modified from Ross, 1968). Fusulinids generally distributed at the depth 0-7 m and become rare around 10-15 m depth. The fusulinids thermocline in this tropical paleolatitude is abnormally shallow, i.e. $140 \mathrm{~m}$ in normal paleotropics vs 10-15 m in North American paleotropics.

Fig. 5. The warming and cooling events along the North American shelves during Pennsylvanian and early Cisuralian. The majority of fusulinid genera at the tropical paleolatitude in North 
America occur as result of the immigration to the region always with lag around 1.5-4 Ma in comparison with their origination in Tethys tropics. The immigration to North America occurred rapidly and abruptly and is likely to have been associated with warming events. At several levels (early Bashkirian, lower upper Moscovian, early Kasimovian and early Sakmarian) the appearance and dispersal of certain fusulinids in North American and Boreal provinces occur isochronous. These levels interpreted to have been associated with cooling events that make environments in both provinces uniform and favorable for the distribution these cool—water faunas. Abbreviations for the North American stages: Morrow. — Morrowan, Desmoin. Desmoinesian, Msr — Missourian, Virgil. — Virgilian, Lnx — lower part of Lenoxian Fig. 6. Warming and cooling events along the North American shelves during late Cisuralian through the end of the Permian. The warming events associated with diversity peaks and occur in late Artinskian, late Kungurian, Capitanian and Changsingian. The cooling events correspond to the low taxonomic diversity interval and proposed to occur in early Artinskian, early Kungurian, Roadian-early Wordian and early Wuchiapingian. Abbreviations for the chronostratigraphic units: Lnx — lower part of Lenoxian. Word. — Wordian; Changsin — Changsingian. 


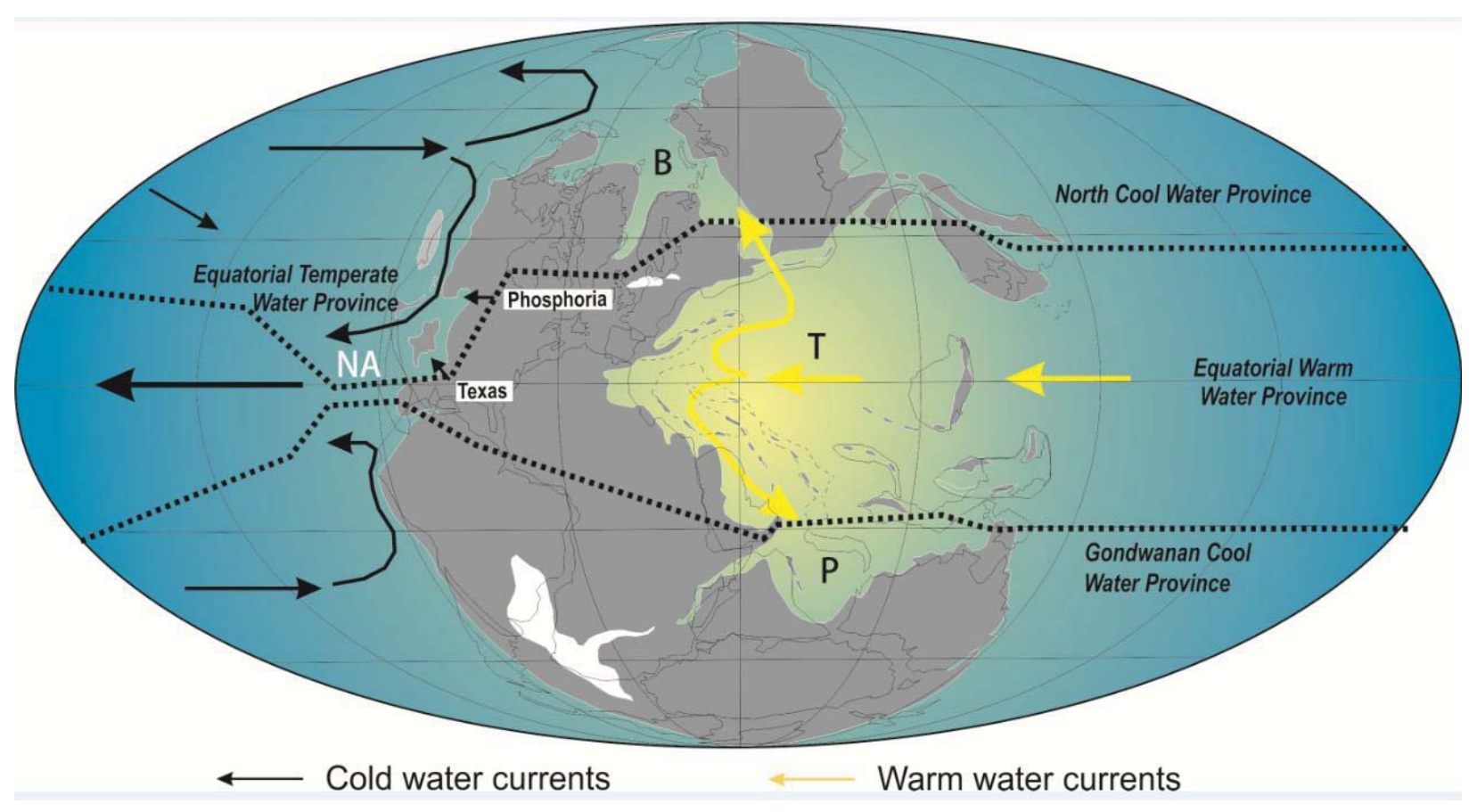

Figure 1 


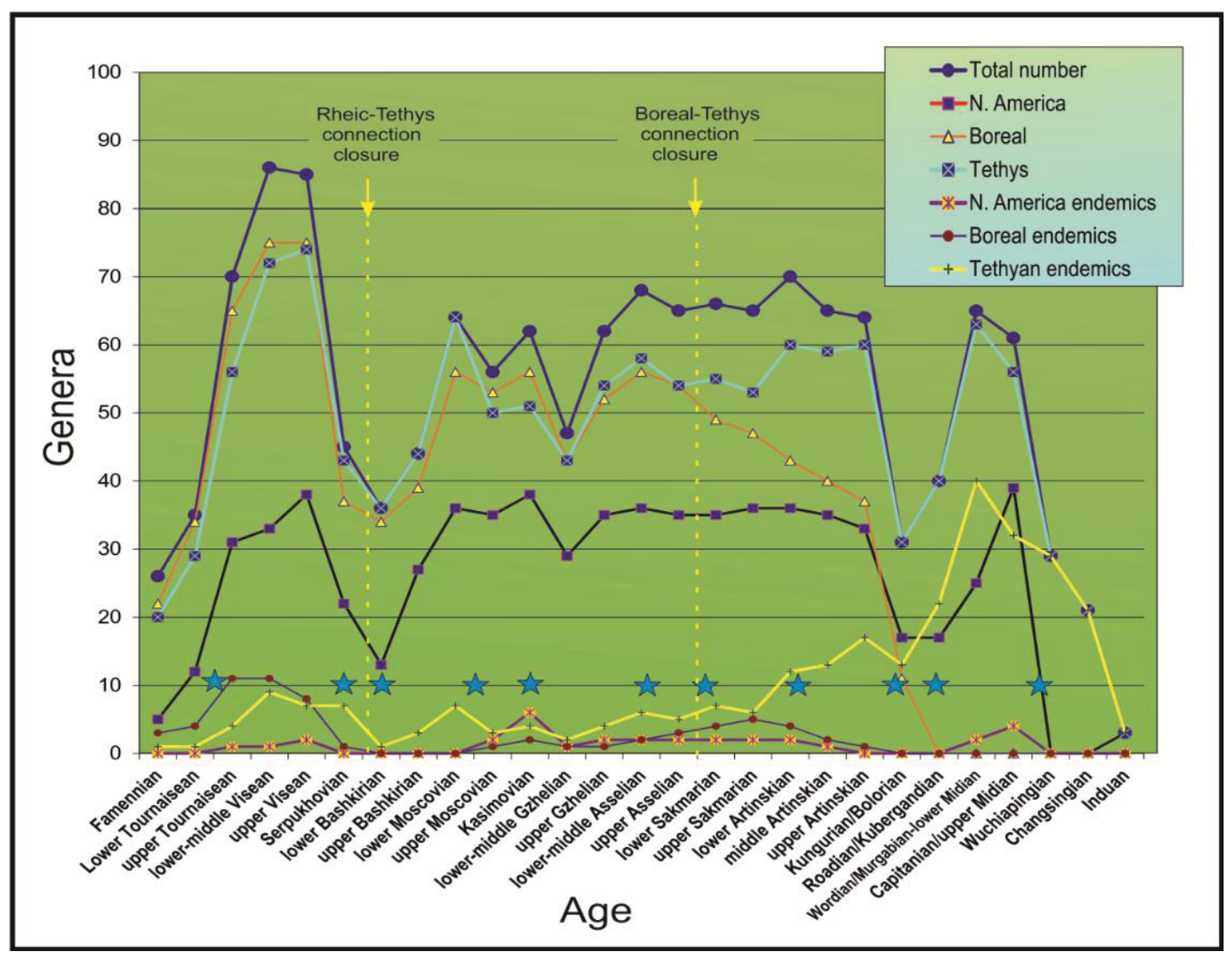

Figure 2 


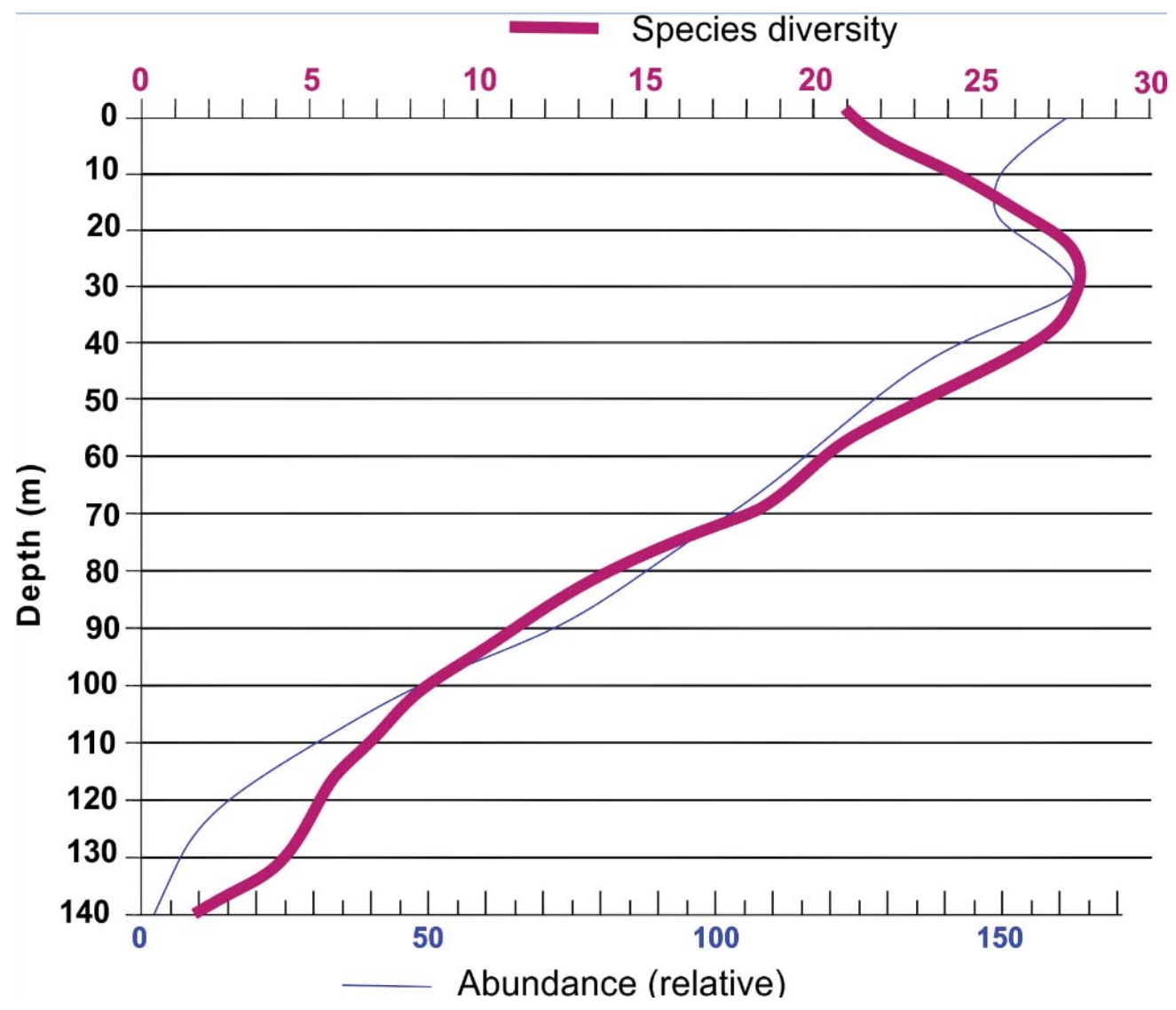

Figure 3 

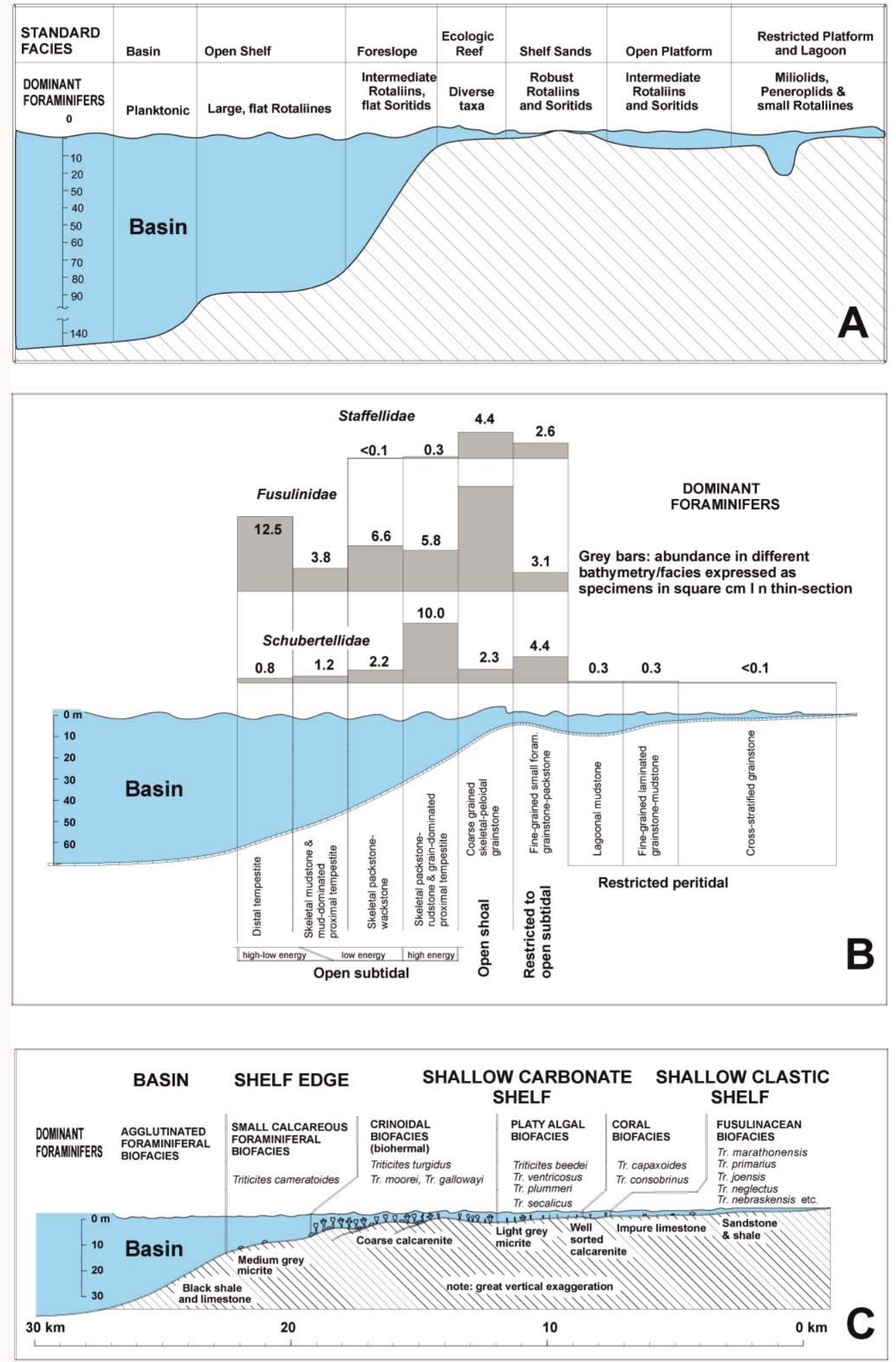

Figure 4 


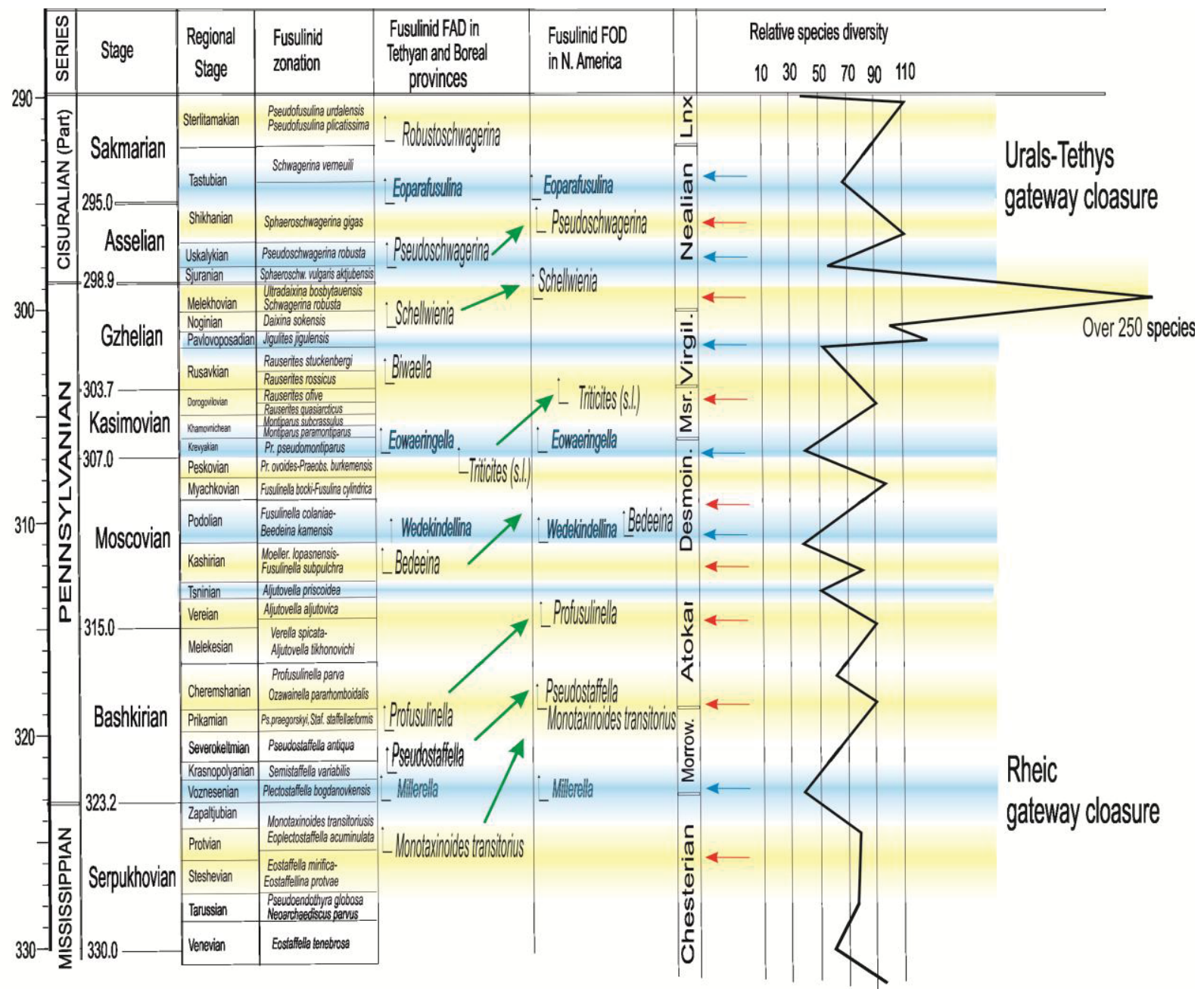

Figure 5 


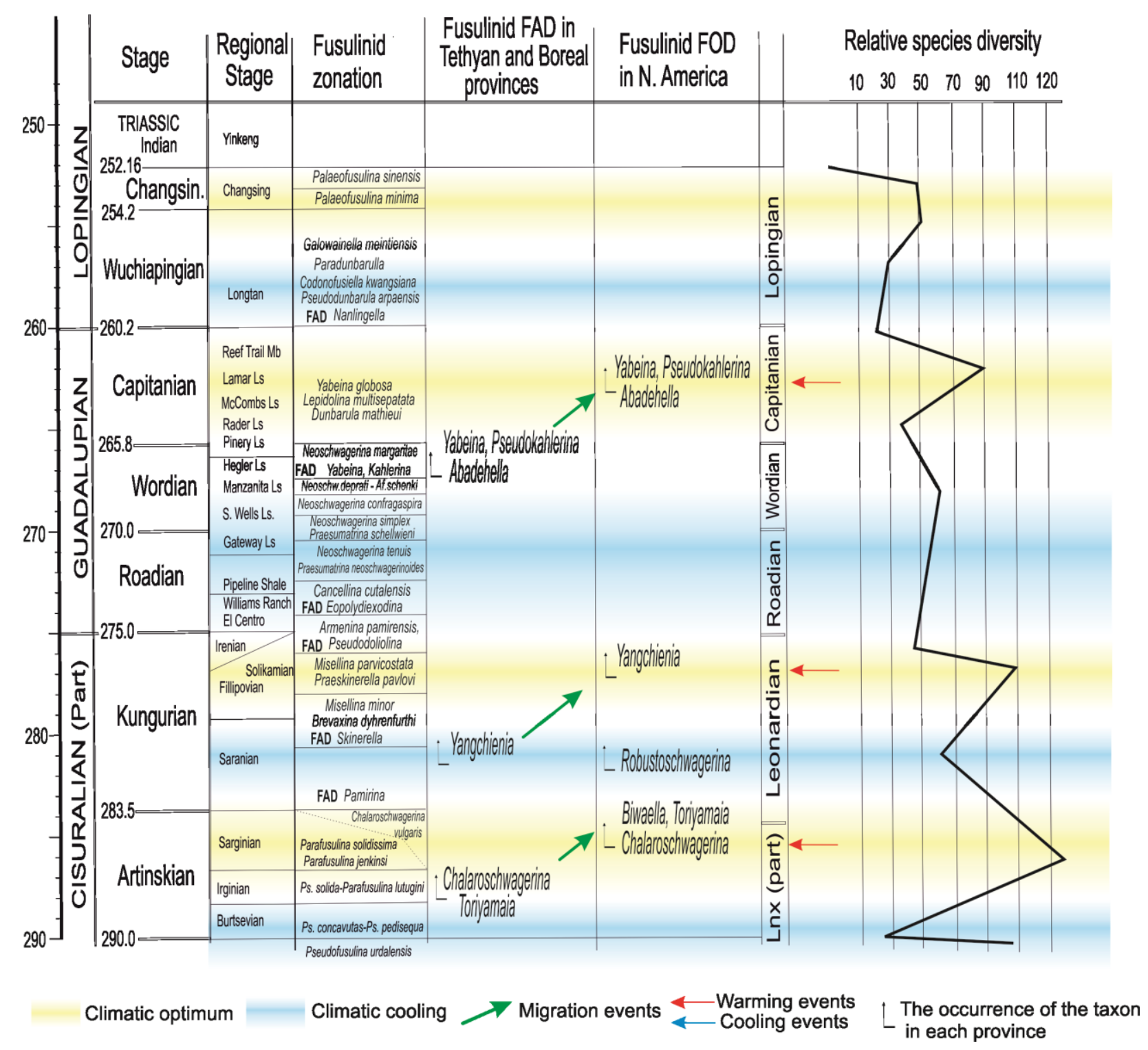

Figure 6 

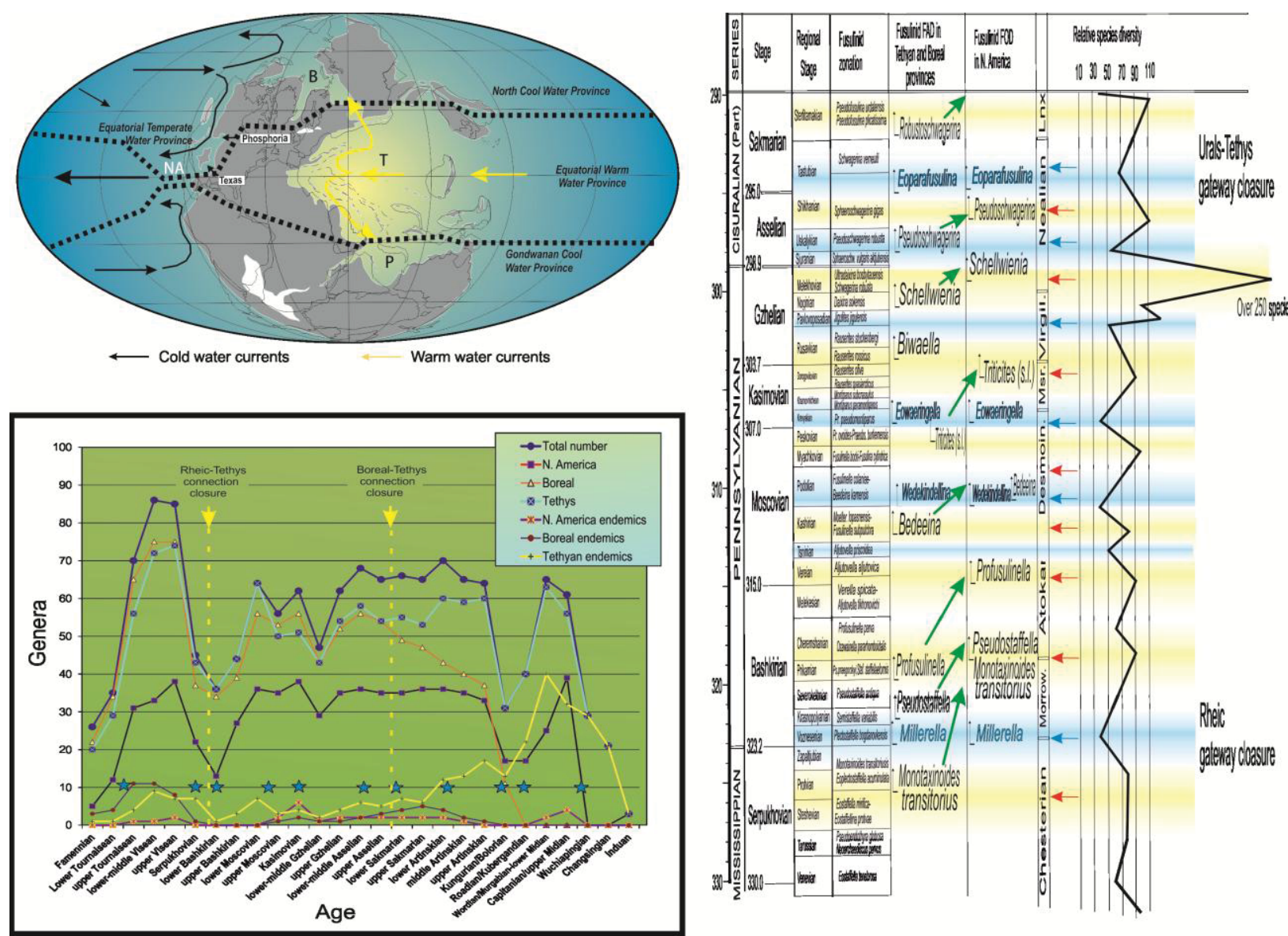

Graphical abstract 


\section{HIGHLIGHTS.}

-Benthic foraminifera constrain paleogeographic and climatic events at a global scale

-The genera in North American appear with the lag of 1-5 Ma in respect of their FAD

-The immigration of the innovative fauna in North America occur during warming events

-Isochronous occurrence some forms in Arctic and North America indicate cooling events

- Paleoclimate in North American shelves in general controlled by global factors 